\title{
Effect of Magnetized Water on Germination and Some Growth Characters of Broad Bean (Vicia Faba L.)
}

\author{
Manhel M. Abd Ellateef ${ }^{1}$, Elnasri M. Mutwali ${ }^{2 *}$ \\ ${ }^{1,2}$ Department of Biology, Faculty of Education, \\ Alzaiem Alzhari University, Sudan \\ *Corresponding author's email: elnasrishaheen [AT] yahoo.com
}

\begin{abstract}
A pot experiment was carried out to study the effect of magnetized water on some growth characters of broad bean (Vicia faba L.). The experiment was arranged in completely randomized design (CRD) with four different treatments of magnetized water and tap water as a control. Results indicated a significant increase in plant height, number of leaves, leaf area, fruit length, weight of 100 seeds. The results also showed a significant increase in some elements ( $\mathrm{K}, \mathrm{Ca}$ and $\mathrm{Mg}$ ). The shoot and root fresh and dry weight and chlorophyll content expressed a significant increase compared to control.
\end{abstract}

Keywords---- Broad bean, Chemical constituents, Germination, Magnetized water 


\section{INTRODUCTION}

Modern agricultural efforts are now in search of an efficient eco-friendly production technology based on physical treatment of seeds and water; these physical technologies are safe for environment and frequently change the course of some physiological processes into increased vigour and improved plant development at later stage [1]. The magnetic field can be used as an alternative to the chemical methods of plant treatment for improving the production efficiency [2]. In Sudan the available studies and the application of magnetic water in agriculture is very limited, therefore, the present work aims to study the effect of irrigation with magnetized water on germination growth and yield of broad bean (Vicia faba L.).

\section{MATERIALS AND METHODS}

\section{Plant materials:}

The broad bean seeds were obtained from the Agricultural Research Centre, Shambat.

\section{Magnetic device:}

The device used for water treatment was funnel shaped obtained from the local agent of (Magnetic Technologies L.L.C. Model Na MFLa, Dubai, U.A.E.).

\section{Seed Germination:}

The seeds of broad bean with uniform size and without seen defect were arranged to five treatments as the following:

1. The first treatment, seeds were irrigated with tap water (the control).

2. The second treatment, seeds were irrigated with magnetic water (once).

3. The third treatment, seeds were irrigated with magnetized water (three times).

4. The fourth treatment, seeds were irrigated with magnetized water (four times).

5. The fifth treatment, seeds were irrigated with magnetized water (six times).

The germination tests were carried out at laboratory conditions. The experiment was conducted as completely randomized design with three replications. Germination tests were performed according to the guidelines issued by the International Seed Testing Association (ISTA)[3]. During the experiment the germinated seeds were counted daily and water was added according to the necessity.

\section{Pot Experiment:}

The soil used in this experiment was river silt, moderately acid $(\mathrm{pH}, 6.75)$, highly permeable.

The experiment was set up in plastic pots $(27 \times 18 \mathrm{~cm})$ and arranged in completely randomized design with three replications. Ten seeds of broad bean were sown in each pot, then thinned to two homogenous seedlings. Measured volume $500 \mathrm{ml} /$ pot of water with or without magnetic treatment was applied in each pot soon after sowing according to the treatments described earlier and then daily during the entire duration of the experiment. The plant heights, number of leaves, leaf area were recorded after 70 days after sowing. The shoot fresh and dry weight, root fresh and dry weights were taken at the end of the experiment. The harvested plants were used for determination of chlorophyll content ( $a, b)$ and part of the dried shoot were digested and used for determination of $\mathrm{N}, \mathrm{P}, \mathrm{K}, \mathrm{Na}, \mathrm{Ca}$ and $\mathrm{Mg}$. the data of the experiment were subjected to analysis of variance (ANOVA) according to [4].

\section{RESULTS AND DISCUSSION}

Table (1) showed an increase in germination percentage, although was not significant. This increment in germination percentage was reported by [5] who observed an increase in germination of Pinus tropicalis seeds with magnetically treated water. Also the work of [6]. [7] and [8]. In this respect [9] reported that a marked positive effect of magnetic treatment on germination and emergence of two broad bean cultivar was observed.

The increase in treatments irrigated with magnetized water may be attributed to the increase in the ability of water absorption and nutrients by the seeds and consequently lead to an increase in germination percentage.

The plant height expressed a significant difference between treatments and control (Table 1). In this connection, [10] found that chick pea plants irrigated with magnetized water were taller than plants irrigated with tap water. Similar results were reported by [11] who found that irrigation flax with magnetized water increased plant height. Also [7] found that plant height of okra increased significantly in the seedlings early treated with magnetic field.

The number of leaves showed a significant increase (Table 1). Similar results were reported by [12] who stated that a significant difference was detected in the number of leaves of okra when used magnetized water against tap water.

The leaf area showed a significant increase in treatments treated with magnetized water compared with control Similar results were reported by [7] who found an increment in leaf area of okra treated with magnetic field compared to 
control. The work of [13] supports this result as he found an increase in leaf area of beans and peas when irrigated with magnetic water.

Table (1): Effect of magnetized water on germination, plant height, number of leaves and leaf area of broad bean

\begin{tabular}{|c|c|c|c|c|}
\hline $\begin{array}{l}\overrightarrow{0} \\
\stackrel{8}{\rightleftarrows}\end{array}$ & $\begin{array}{l}\text { Germination } \\
\text { percentage }\end{array}$ & $\begin{array}{l}\text { Plant } \\
\text { height } \\
(\mathrm{cm})\end{array}$ & $\begin{array}{c}\text { Number } \\
\text { of } \\
\text { leaves }\end{array}$ & $\begin{array}{c}\text { Leaf } \\
\text { area } \\
\left(\mathrm{cm}^{2}\right)\end{array}$ \\
\hline $\mathrm{T}_{1}$ & 48.89 & 36.00 & 17.33 & 6.76 \\
\hline $\mathrm{T}_{2}$ & 50.56 & 42.16 & 21.00 & 9.07 \\
\hline $\mathrm{T}_{3}$ & 52.22 & 42.20 & 21.50 & 9.06 \\
\hline $\mathrm{T}_{4}$ & 50.00 & 42.66 & 20.83 & 9.23 \\
\hline $\mathrm{T}_{5}$ & 49.50 & 42.83 & 19.83 & 8.95 \\
\hline LSD & 20.37 & 6.14 & 1.73 & 0.15 \\
\hline
\end{tabular}

The increment in leaf area might be due to the increased photosynthetic rates due to greater interception of light [14].

The shoot fresh and dry weight of broad bean showed a significant increase in treatments irrigated with magnetized water against control (Table 2). Similar results were reported by [11] who reported an increase in shoot fresh and dry weight of flax when irrigated with magnetized water. These results concur with the results of [15] who found a significant increase in shoot fresh and dry weight of common bean when treated with magnetic water.

Table (2): Effect of magnetized water on shoot fresh and dry weight, root length and root fresh and dry weight of broad bean

\begin{tabular}{|c|c|c|c|c|c|}
\hline $\begin{array}{l}\vec{\oplus} \\
\stackrel{\oplus}{*}\end{array}$ & $\begin{array}{l}\text { Shoot } \\
\text { fresh } \\
\text { weight } \\
(\mathrm{g})\end{array}$ & $\begin{array}{c}\text { Shoot } \\
\text { dry } \\
\text { weight } \\
(\mathrm{g})\end{array}$ & $\begin{array}{l}\text { Root } \\
\text { length } \\
(\mathrm{cm})\end{array}$ & $\begin{array}{c}\text { Root } \\
\text { fresh } \\
\text { weight } \\
(\mathrm{g})\end{array}$ & $\begin{array}{c}\text { Root } \\
\text { dry } \\
\text { weight } \\
(\mathrm{g})\end{array}$ \\
\hline $\mathrm{T}_{1}$ & 4.15 & 0.60 & 4.10 & 0.66 & 0.15 \\
\hline $\mathrm{T}_{2}$ & 5.25 & 0.98 & 6.64 & 1.90 & 0.47 \\
\hline $\mathrm{T}_{3}$ & 5.80 & 0.99 & 6.86 & 1.85 & 0.42 \\
\hline $\mathrm{T}_{4}$ & 5.82 & 0.98 & 6.76 & 1.80 & 0.43 \\
\hline $\mathrm{T}_{5}$ & 5.80 & 0.97 & 6.71 & 1.78 & 0.42 \\
\hline LSD & 1.59 & 0.38 & 2.58 & 0.92 & 0.23 \\
\hline
\end{tabular}

These results may be attributed to the role of magnetized water in increasing absorption and assimilation of nutrients consequently increasing plant growth and hence the shoot fresh and dry weight.

The root length, root fresh and dry weight showed a significant increase in treatments irrigated with magnetized water compared with control. [16] reported that irrigation of sugar beet with magnetized water induced significant increases in root length, root weight and diameter compared with non-magnetized water.

Concerning the chemical elements of broad bean, Table (3) showed that an increase in N, P, and Ca content was observed in treatments irrigated with magnetized water compared with control. However, potassium, $\mathrm{K}$ and magnesium $\mathrm{Mg}$ expressed a significant difference $(\mathrm{P}=0.05)$ between treatments and control. Similar results were reported by [17] who found an increase in concentration of $\mathrm{N}, \mathrm{K}, \mathrm{Ca}, \mathrm{Mg}$ of strawberry plant leaves compared with the control. These results were supported by the findings of [18] who reported that shoot $\mathrm{N}, \mathrm{P}$ and $\mathrm{K}$ contents of faba bean was significantly increased by using different magnetized irrigation water compared with the normal or non-magnetized water. Also [19] reported that an increase in concentration of $\mathrm{N}, \mathrm{K}, \mathrm{Ca}, \mathrm{Mg}$ of cotton leaves was observed.

Table (3): Effect of magnetized water on some elements of broad bean.

\begin{tabular}{|c|c|c|c|c|c|c|c|}
\hline \multirow{2}{*}{$\begin{array}{c}\overrightarrow{8} \\
\stackrel{F}{F}\end{array}$} & $\begin{array}{c}\mathrm{Na} \\
\%\end{array}$ & $\begin{array}{c}\mathrm{P} \\
\mathrm{ppm}\end{array}$ & $\begin{array}{c}\mathrm{K} \\
\mathrm{ppm}\end{array}$ & $\mathrm{Ca}$ & $\mathrm{Mg}$ & (a) & (b) \\
\hline $\mathrm{T}_{1}$ & 2.02 & 5.80 & 524.0 & 1.12 & 1.15 & 2.185 & 0.85 \\
\hline $\mathrm{T}_{2}$ & 2.73 & 5.86 & 697.0 & 1.76 & 1.67 & 2.252 & 0.94 \\
\hline $\mathrm{T}_{3}$ & 2.88 & 5.90 & 699.0 & 1.92 & 1.65 & 2.264 & 0.86 \\
\hline $\mathrm{T}_{4}$ & 2.80 & 5.90 & 612.0 & 2.08 & 1.66 & 2.330 & 1.05 \\
\hline
\end{tabular}




\begin{tabular}{|c|c|c|c|c|c|c|c|}
\hline$T_{5}$ & 2.84 & 582 & 562.0 & 2.08 & 1.57 & 2.206 & 0.87 \\
\hline LSD & 1.91 & 1.87 & 25.30 & 1.10 & 0.26 & 0.81 & 0.080 \\
\hline
\end{tabular}

The chlorophyll content ( $\mathrm{a}$ and $\mathrm{b}$ ) increased in treatments treated with magnetized water compared with the control. In this respect, [20] showed an increase in chlorophyll and carotenoids content specifically appeared after treatment with magnetic water.

[21] reported that the chlorophyll a, b and carotenoids increased significantly in plants irrigated with magnetized water as compared to the control. [22] confirmed that magnetic field significantly increased chlorophyll a, b and total chlorophyll contents in soy bean (Glycine $\max$ L.).

The increase in photosynthetic pigments may be attributed to increasing ions mobility and ions uptake improved under magnetic field, which leads to a better photo-stimulation in plants [23].

Table (4) showed some yield components. A significant increase was observed in fruit length in treatments treated with magnetized water compared with the control. Similar results have been reported in barley, sunflower, cotton and lettuce [24].

Table (4): Effect of magnetized water on fruit length, number of fruits/plant, number of seeds/fruit and weight of 100 seeds.

\begin{tabular}{|c|c|c|c|c|}
\hline Treat. & $\begin{array}{c}\text { Fruit length } \\
(\mathrm{cm})\end{array}$ & $\begin{array}{c}\text { No. of } \\
\text { fruit/ plant }\end{array}$ & $\begin{array}{c}\text { No. of } \\
\text { seeds/fruit }\end{array}$ & $\begin{array}{c}\text { Weight of } \\
100 \text { seeds }(\mathrm{g})\end{array}$ \\
\hline $\mathrm{T}_{1}$ & 2.80 & 1.20 & 2.00 & 1983 \\
\hline $\mathrm{T}_{2}$ & 5.60 & 2.40 & 2.33 & 32.17 \\
\hline $\mathrm{T}_{3}$ & 5.10 & 2.16 & 3.00 & 46.67 \\
\hline $\mathrm{T}_{4}$ & 4.67 & 1.67 & 2.33 & 40.33 \\
\hline $\mathrm{T}_{5}$ & 4.57 & 2.10 & 2.67 & 41.20 \\
\hline $\mathrm{LSD}$ & 2.30 & 1.81 & 1.91 & 5.63 \\
\hline
\end{tabular}

The number of fruits per plants showed an increase in treatments treated with magnetized water compared with the control. Similar results obtained by [7], [26], [13]. The number of seeds/pod increased in treatment treated with magnetized water compared with control. These results were supported by the results of [9] who reported that magnetic field increased the number of seeds in plants grown from the treated seeds than that from tap water.

The weight of 100 seeds in treatments irrigated with magnetized water showed a significant increase as compared with control (Table 4). In this respect [25] concluded that, magnetic field was shown to induce fruit yield/plant and average fruit weight.

The increased in seed yield was a consequence of the increased number of pods of broad bean as treated with magnetized water.

\section{Conclusion:}

It seems that the use of magnetized water can lead to increase some morphological and physiological characters of broad bean, and increase the yield.

\section{REFERENCES}

[1] Carbonell, M.V., Martinez, E. and Amaya, J.M. (2000). Stimulation of germination in rico (Oryza sativa L.) by a static magnetic field electro and magneto biology, 19(1): 121-128.

[2] Aladjadjiyan, A. (2002). Study of the influence of magnetic field on some biological characteristics of Zea mays. J. Cent. Eul. Agric., 3: 89-94.

[3] ISTA International Rules for Seed Testing (2007). International Seed Testing Assoc. Zurich, Switzerland.

[4] Gomez, A.K. and Gomez, A.A. (1984). Statistical procedures for agricultural research. John Willey and Sons, Inc. Canada.

[5] Morejon, I.P., Castro, J.C., Velgazquez, L.G. and Gorea, A.P. (2007). Stimulation of Pinus tropicalis seeds by magnetically treated water. Int. Agrophys, 21: 173-177.

[6] Cakmak, J., Dumlupinar, R. and Eradal, S. (2010). Acceleration of germination and early growth of wheat and bean seedlings grown under various magnetic field and osmotic conditions. Bio-electromagnetic. 31: 120-129.

[7] Naz, A. Jamil, Y., Hag, Z., Iqbal, M., Ahmed, M.K., Ashraf, M.I. and Ahmed, R. (2012). Enhancements in the germination, growth and yield of okra (Abelnoschus esculentus) using pre-sowing magnetic treatment of seeds. Indian Journal of Biochemistry \& Biophysics. 49: 211-214. 
[8] Samani, M., Pourakbar, L and Azimi, N. (2013). Magnetic field effects on seed germination and activities of some enzymes in cumin. Life Sci. Jour, 10(1): 135-137.

[9] Podlesny, J., Pietruszewski, S, Podlesna, A. (2004). Efficiency of magnetic treatment of band beanseeds cultivated under experimental plot conditions Int. Agrophysics, 18: 65-71.

[10] Nasher, S.H. (2008). The effect of magnetic water on growth of chick-pea seeds. Eng. \& Tech., $26(9): 4$.

[11] Abdul Qados, A.M.S. and Hozayn, M. (2010). Response of growth, yield and yield components and some chemical constituents of flax for irrigation with magnetized and tap water. World appl. Sci. J., 8(5):630-634.

[12] Bashir, A.A.E.M. (2006) evaluation of magnetic technology for vegetable production under drip irrigation system M.Sc. Thesis, Faculty of Agriculture, University of Khartoum.

[13] Deshpande Mrunal (2014). Effect of magnetic water on growth of leaves. European J. of Applied Engineering and Scientific Research, 393): 9-12.

[14] Vashisth, A. and Nagarajans, A. (2010). Effect on germination and early growth characteristics in sunflower (Helianthus annus L.) seeds exposed to static magnetic field. Journal of plant Physiology, 167: 149-156.

[15] Moussa, H.R. (2011). The impact of magnetic water application for improving common bean (Phaseolus vulgaris L) production. New York Sci Journ. 4(6): 15-20.

[16] Hozayn, M., Abdel Monem, A.A. Abdel Ruouf, R.E. and Abdalla, MM (2013). Do magnetic water affect water use efficiency, quality and yield of sugar beet (Beta vulgaris L.) plant under arid regions conditions? Journal of Agronomy, 12(1): 1-10.

[17] Maheshwari, L. and Grewal, H.S. (2009). Magnetic treatment of irrigation water: its effects on vegetable crop yield and water productivity. Journal of Agricultural Water management, 96: 1229-1236.

[18] Mohamed, A. and Ebea, B.M. (2013). Effect of irrigation magnetically treated water on faba bean growth and composition. Intern. J. of Agric. Policy and Res, 1(2): 024-00.

[19] Bilalis, J.D., Katsenios, N., Efthimiadou, A., Karkanis, A., Khah, M.E. and Mitsis, T. (2013). Magnetic field presowing treatment as an organic friendly technique to promote plant growth and chemical elements accumulation in early stages of cotton. Australian Journal of Crop Science (1): 46-560.

[20] Mihaela, R., Simona, M. and Dorina, E.C (2009). The response of plant tissues to magnetic fluid and electromagnetic exposure, Rom. J. Phys., 19(1): 73-82.

[21] Al-Khazan, M. and Abdullatif, BM. (2011). Effect of magnetically treated water on water status, chlorophyll pigments and some elements content of jojoba (Simmondsia chinensis L.) at different growth stages. African Journal of Enviro. Sci. and Tech, 5(9): 722-731.

[22] Atak, C., Emiroglu, O., Alikamamnoylus and Rzakouliera, A (2003). Stimulation of regeneration by magnetic field in soybean (Glycine max L Merrill) tissue cultures. J. Coll. Mol. Biol., 2: 113-118.

[23] Pietruszewski, S.T. (1999). Influence of pre-sowing magnetic bio-stimulation on germination and yield of wheat, Int. Agro-Physics, 13: 241-244.

[24] Reina, F.G. and Pascual, L.A. (2001). Influence of stationary magnetic field on water relation in lettuce seeds, Part I: Theoretical Considerations, Bioelectro-magnetic, 22: 589-595.

[25] Esitken, A. and Turan, M. (2004). Alternating magnetic field effects on yield and plant nutrient element composition of strawberry (Fragaria amgnassa cu. Coamarosa). Acta Agric. Scand Sat B. Soil Plant Sci., 54:135-139.

[26] Celik, O., Atak, C.A. and Rzakulieva, A. (2008). Stimulation of rapid regeneration by a magnetic field in paulownia node cultures. J. of Central Europ. Agric. 9(2): 297-303. 